\title{
Thailand's 2011 Flood: Household Damages, Compensation and Natural Catastrophe Insurance
}

\author{
Orapan Nabangchang \\ Sukhothai Thammatirat Open University, Nonthaburi, Thailand \\ Hermi Francisco \\ Economy and Environment Program for Southeast Asia, Los Banos, Philippines \\ Aini Zakaria \\ Economy and Environment Program for Southeast Asia, Penang, Malaysia
}

\begin{abstract}
This study looks into how households' experience with the July-December 2011 flooding in Thailand influences their desire to have flood insurance coverage. It also evaluates coverage and flood depth as the two salient features of the National Catastrophe Insurance Fund (NCIF), which was established in March 2012 in response to the 2011 Thailand flooding. Altogether 600 households were interviewed in this study to represent the middle and poor households from three areas in Thailand: Nonthaburi, Bangkok, and Pathum Thani. The households' flood experience was represented by three variables: (1) damages incurred; (2) compensation received; and (3) level of the flood depth inside their houses. The household survey revealed that damages averaged USD 2,393 for poor households and USD 8,087 for middle households with average flood depth being $127 \mathrm{~cm}$ and $83 \mathrm{~cm}$, respectively. Computed damage cost includes both direct costs (damages to property and expenses to repair or replace, cleanup costs) and indirect costs (time spent of family members and volunteer workers as well as loss of earnings). Middle and poor households affected by the floods received compensation from the government averaging at USD 683 to USD 734. The NCIF offers a maximum coverage of THB 100,000 (USD3,100) for a maximum flood depth of $1 \mathrm{~m}$ inside the house. This is clearly higher than compensations received, particularly since low-income households experienced an average flood depth of $127 \mathrm{~cm}$. Unfortunately, these households had no insurance coverage. The same is true for the middle-income households. At $83 \mathrm{~cm}$, had they secured a disaster insurance, the coverage received would have been higher than the compensation they received from the government. Unfortunately only $7 \%$ of those interviewed had disaster insurance coverage. What prevents people from getting insurance? This study found out that despite the bad experience from Bangkok flooding and that over half believed that there is more than $70 \%$ chance that a flood as severe as 2011 will reoccur in the next five years, only 22\% of low income households and 37\% of middle income households would be willing to purchase disaster insurance. Factors affecting this willingness include: having prior information about the NCIF flood insurance, age and, value of house with households having younger
\end{abstract}

*Acknowledgement: The authors would like to thank Dr. Dale Whittington and Ms. Maura Allaire from University of North Carolina, USA, for their contributions to this study.

Orapan Nabangchang, Ph.D., asssociate professor, School of Economics, Sukhothai Thammatirat Open University; Deputy

Director of the Economy and Environment Program for Southeast Asia (EEPSEA).

Hermi Francisco, Director of EEPSEA, Los Banos, Philippines.

Aini Zakaria, Researcher Manager of EEPSEA, Penang, Malaysia.

Correspondence concerning this article should be addressed to Orapan Nabangchang, School of Economics, Sukhothai

Thammatirat Open University, Tambon Bang Pud, Pakkret District, Nonthaburi, Thailand. E-mail: orapann@gmail.com. 
decision-makers, higher house prices and being more likely to purchase flood insurance.

Key words: Thailand 2011 flood, damage assessment, compensation, catastrophe insurance

\section{Introduction}

\section{The Rationale of the Study}

In year 2011, Thailand was hit by the worst floods experienced in 50 years. What made the 2011 devastating was a confluence of several factors (Suppaisarn, 2011). Firstly, the recorded rainfall in that year was the highest having five consecutive tropical storms in the mid rainy seasons. Secondly, the higher than average volume of water runoff from the major rivers was believed to have been confounded by the unsuitable land use in the flood plains. Lastly, these natural and man-made causes were accompanied by alleged flood mismanagement of the government during that period. During those flooding months, 69 provinces were affected with the total flood inundation area of 41,381.8 square km (GISTDA, 2011). Death tolls reached 815 deaths and three persons were reported missing ${ }^{1}$. Nearly 2.08 million hectares of agricultural land were damaged and the transportation of goods and services particularly food supplies were crippled because major roads were impassable.

Immediately following the event, three major studies were undertaken to estimate the economic value of the flood damages. The World Bank did a rapid assessment of losses using the Damage and Loss Assessment (DALA) methodology (World Bank, 2012). The analysis covers losses from agriculture, industry, tourism, finance, and insurances as well as damages and losses in the infrastructure and social sectors. Overall, the total damage and loss amounted to THB 1.43 trillion (USD 46.5 billion), with losses accounting for 56\% of the total. $^{2}$ The same study estimated that recovery and reconstruction would cost USD 50 billion. The Thailand Development Research Institute (TDRI) also did a similar research by estimating the impact of the flooding on household income and expenditure in 26 flooded provinces using secondary data from 2011 Socio-economic Survey, and information about flooded areas from satellite radar images. The results have shown that the flooding reduced total household expenditures by 5.7\% to 14\% (Poapongsakorn \& Meethom, 2012). The third study, its findings on which this paper is based, was initiated by the Economy and Environment Program for Southeast Asia (EEPSEA). The study focused on flooding damages in residential areas in Bangkok and vicinity provinces using primary data from 600 households who were affected by the 2011 flooding. The main goal was to assess the extent and nature of damages at the household level by looking at indirect and direct costs in preparation for the flooding, during the flooding and during the cleanup operations. A more detailed account of the nature of damages to protect themselves from the incoming floods (Pre-Flood event), losses incurring throughout the inundation period, and costs incurring for rehabilitation after the flooding event are discussed in a separate paper (Nabangchang, Allaire, Leangcharoen, Jarungrattanapong, \& Whittington, 2014). This paper is focused on a study on the demand for flood insurance. As a response to the 2011 flooding, the government set up a NCIF to provide flood insurances coverage since private insurance providers suffered huge losses from that big flooding event and hence would not cover flooding insurance without co-financing from the government. The NCIF is thus a partnership between private insurers and the government. In this scheme,

\footnotetext{
1 Department of Disaster Mitigation and Prevention, Ministry of Interior.

2 Damage refers to direct impacts on physical assets, products, raw materials, machinery, and properties. Losses refer to reduced or lost production opportunities, i.e., loss of income, reduced production efficiency, and increasing expenditures over a period of time (World Bank, 2012, p. 17).
} 
insurance companies are required to bear a minimum risk of $0.5 \%-1 \%$, while the remaining risk will be reinsured by the NCIF. "Catastrophe Insurance Policy" will offer coverage for damages caused by the three types of natural disaster, namely, floods, earthquake, and windstorm. In a period of one year since March 2012 and 2013, the Office of Insurance Commission (OIC) reported that 808,119 contracts have been bought, 591,167 contracts or $92 \%$ of the total issued were flood insurances bought by households and $42 \%$ of the total were bought by households in five provinces assessed to be among the high flood risk areas which included the three provinces of our study sites, namely, Nonthaburi, Bangkok, and Pathum Thani. The number of households who have purchased flood insurance represents $16.7 \%$ of the households in Nonthaburi and $14.3 \%$ of households in Pathum Thani. For one of the flooded district of Bangkok and also our study area, Don Muang, $17.5 \%$ of the households are reported to have purchased flood insurance (Figure 1). This paper looked into factors that drive demand for flood insurance based on household survey almost one year after the 2011 flood. Comparisons were made between the damage costs incurred by households, the compensations received and coverage offered by the flood insurance. This paper focused on the comparison of damages with compensation received and demand for insurance.

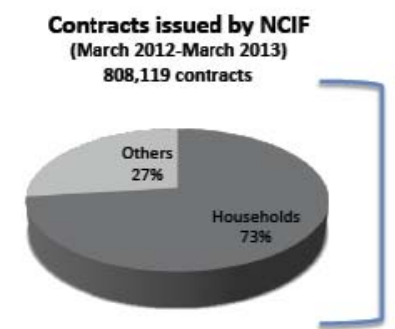

Nontaburi

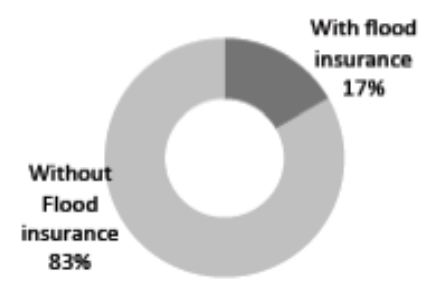

Bangkok (Don Muang District)

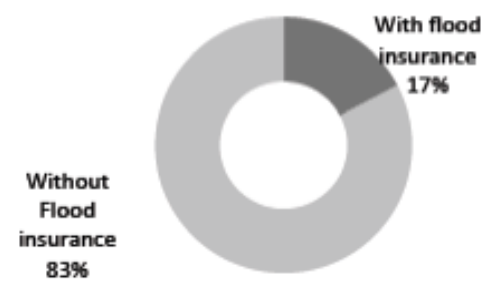

Pathum Thani

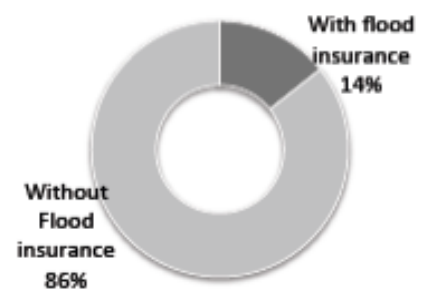

Figure 1. Existing situation on disaster insurance.

The following section contains details of site selection, sampling and analytical frame for analyzing the components of the economic losses and factors associated with the extent of the damages as well as factors which influence household choices about purchasing flood insurance. This is discussed in conjunction with information on compensation. This leads into the section on demand for flood insurance as one possible way to minimize the losses. The final section concludes with our observations about the extent of the damages and factors, which underlie households' decisions about whether or not to buy flood insurance.

\section{Methodology}

Site selection. Household surveys were conducted in three areas in Bangkok and two vicinity provinces which were among the hardest hit by the 2011 flood, namely, in Nonthaburi, Pathum Thani, and Bangkok. In these provinces, three districts were purposively selected: Bang Bua Thong District (Nonthaburi located west of 
Bangkok), Klong Luang District (Pathum Thani located north of Bangkok), and Don Muang District (northern Bangkok) $)^{3}$. They were selected because of the difference in the speed of the rise in the depth of the water, which might affect extent, and nature of flooding damages. In Bang Bua Thong (Nonthaburi) the floodwaters rose to their maximum level within 24 hours. In Klong Luang (Pathum Thani) the floodwaters rose more gradually, $0.5 \mathrm{~m}$ in one week. The Don Muang District of Bangkok flooded before the other two study sites and water rose at a moderate pace ( 0.8 meters within 24 hours).

Sampling. The sampling area covered 12 neighbourhoods, four neighbourhoods from each district, which comprise two middle-income neighborhoods and two low-income neighborhoods. For each neighbourhood, a quota of 50 respondents was set. During January and February 2012, altogether 600 hundred respondents were interviewed. ${ }^{4}$ At the time of the first round survey, households would have either just returned to their houses and would have just started to clean and restore the damages and not all the post-flood expenses would have been incurred, particularly for repair and replacement of what has been damaged. The location of all households was therefore geocoded for purpose of returning to administer a follow up survey once considerable times have passed.

The second round survey was administered 12 months afterwards during February 2013. Apart from following up on expenses to restore the houses and property back to the pre-flood conditions, in this second round survey, additional questions were added to explore the demand for household flood insurances which was among the measures offered to reduce the costs of flood damages. A total of 469 respondents or $78 \%$ of the households in the first round survey were re-interviewed. The analysis in this paper is therefore based only on the information of these 469 respondents who were interviewed in both round 1 and round 2 surveys.

\section{Framework for Estimating Economic Impacts at the Household Level}

Economic costs of floods are sometimes separated into tangible and intangible components (Dutta, Herath, \& Musiake, 2003; Smith \&Ward, 1998; Thieken, Muller, Kreibich, \& Merz, 2005). Tangible components refer to items that can be expressed in financial terms such as damages to properties, buildings and disruptions to normal business operations. Intangibles components on the other hand refer to the effects that are visible such as psychological impacts, yet methodologically challenging to capture in monetary terms.

In both rounds of our households surveys, questions were posed on how people felt, whether or not life has returned to normality as well as perceptions about the reoccurrence of a flood as severe as 2011. While such information contributed to better understanding of how people felt, no attempts are made however to convert these psychological effects in monetary terms and in this paper, only tangible components are taken into account.

On the tangible components, distinctions are made between direct and indirect economic costs. Much of the flood loss literature focuses on direct tangible damages to property (Merz \& Thieken, 2004). In this paper, direct costs refer to financial expenditures household to prevent their houses and property from being damaged before the flood such as hired labour, construction materials such as concrete blocks, cements and sandbags and expenses during the flood and after the flood to restore house and property to livable conditions such as

\footnotetext{
${ }^{3}$ Through the paper, these three districts will be referred to by the name of the provinces they are located in, namely Nonthaburi, Bangkok, and Pathum Thani.

${ }^{4}$ For the low-income neighborhoods in Bang Bua Thong District (Nonthaburi) the response rate was 93\% compared to 68\% in the middle-income neighborhoods (Chollada and Pattaraniwetr). In the Klong Luang District (Pathum Thani) the response rate was of $97 \%$ and $61 \%$ for the low income and middle income neighborhoods, respectively. For Don Muang District (Bangkok) response rate was $91 \%$ for the lower income group and $61 \%$ for the middle-income group.
} 
cleaning, repairing, and replacing.

Like many previous studies, the analysis of indirect tangible components does not take into consideration depreciated property and business value (White, Kates, \& Burton, 2001). Indirect costs focused only on the computed value of time allocation of members of the family labour as well as volunteer workers spent in making precautionary measures before the flood to prevent water from coming into the house as well as cleaning and repairing activities. Indirect costs were calculated as the product of a monetary value of lost productivity, days of work missed, and increased travel time to work and home. The value of lost productivity was estimated based on the respondent's self-reported income. For all other household members, it was assumed that the value of lost time was the minimum daily wage rate in Thailand (THB 300, USD 9.7).

Estimates of the economic costs covered three time periods: (1) ex-ante preventative costs referring to measures households took to try and prevent or reduce the extent of the damages such as parking cars in alternate locations and purchased goods to prepare for the flood such as construction materials, sandbags, and small boats; (2) during the flood costs included coping costs such as increased expenses to commute to work and home, increased food expenditure. For those who evacuated, there was also an increase in accommodation and other necessities. Also computed into monetary value was increased travel time to commute between home and the work place and for some who was not able to work or had to temporarily close down businesses, foregone income; and (3) ex-post losses after the flood included expenditures for car repairs and to repair, clean, and replace housing and other property damage.

\section{Model Specification for Factors Associated With Household Economic Losses and Factors Influencing Demand for Flood Insurance}

Regression analysis was used to estimate the association between household total damages and a number of household characteristics variables. The model specification is presented below:

Household total damage $=\beta_{0}+\beta_{1}$ est_hh_inc $+\beta_{2}$ houseprice $+\beta_{3}$ flood depth $+\beta_{4}$ duration where:

Household total damage $=$ Household direct and indirect cost (minus compensation);

est_hh_inc = Income of all income earners within the household;

House price $=$ Reported house price;

Flood depth $=$ Water depth inside the house.

Logistic regression analysis was used to explore factors, which influenced decision whether or not to purchase flood insurance. The model specification is presented below:

Willingness to purchase $=\beta_{0}+\beta_{1}$ Insurance $+\beta_{2}$ Houseownership $+\beta_{3}$ Houseprice flood insurance $+\beta_{4}$ Story $+\beta_{5}$ Age $+\beta_{6}$ Edu $+\beta_{7}$ Total damage $+\beta_{8}$ Height $4+\beta_{9}$ Duration $4+\beta_{10}$ Risk perception where:

Know_insurance $=$ Whether or not respondents knew about NCIF flood insurance $(1=$ if respondents know about NCIF flood insurance; 0 = if otherwise);

Houseownership $=$ Whether or not respondent is the owner of the house (yes $=1 ; 0$ if otherwise);

Houseprice $=$ Respondent's reported house price;

Story = Number of stories of the house;

Age = Age of respondent;

Edu = Number of years of education; 
Total damage $=$ Household direct and indirect cost (minus compensation);

Height 4 = Water depth inside the house;

Duration 4 = Number of days water remained inside the house;

Risk perception $=$ Respondent's assessment whether or not there will be a major flood as severe as 2011 (on a scale of 0 to $10 ; 1=$ if respondent think there is $70 \%$ or higher probability of flood reoccurring; $0=$ if otherwise);

b_Bangkok = Dummy variable; Bangkok respondents $=1 ; 0$ if otherwise;

B_Nonthaburi = Dummy variable; Nonthaburi respondents $=1$; 0 if otherwise;

B_Pathum Thani $=$ Dummy variable; Pathum Thani respondents $=1 ; 0$ if otherwise

Low \& middle = Dummy variable; middle income respondents $=1$; low income respondents $=0$.

\section{Findings}

As indicated earlier, the households' flood experience was represented by three variables: (1) damages incurred; (2) compensation received; and (3) level of the flood depth inside their houses and if this led to evaluation. These three variables will be discussed in the succeeding sections.

\section{Flood Depth and Proportion of Households Who Evacuated}

For flood depth, four pieces of information were asked, namely, the level of water in the nearest main road as well as in the side street since this would affect the accessibility and the level of the water in the grounds of the house and inside the house. Flood depth information was collected in Round 1 survey between January and February 2012 when it was possible to obtain accurate information on depth by measuring the depth up to the highest watermark stains, which were still highly visible. In Table 1 for flood depth on the main road, Nonthaburi and Bangkok's flood depth were similar at around 1.5 meters. Pathum Thani's average depth was somewhat lower at 0.83 meters. Flood depth inside the house however is comparable for all three districts. What should also be noted is that the flood depth inside the house for those living in low and middle-income neighbourhood is significantly higher than the middle-income neighbourhoods in all three districts. The biggest difference was Bangkok where the flood depth inside the house of respondents in low-income neighbourhood was on average 0.95 meters higher.

In terms of duration of the flood, it took around 67 days in Nonthaburi before water is completely drained from inside the house, on average nine days longer than in Pathum Thani and 19 days longer than in Bangkok. In relation to the differences in flood depth inside the house, the number of days that inside the house in low-income communities remained flooded was significantly longer than the middle-income households.

Table 1

Neighbourhood Profile, Flood Depth, and Duration

\begin{tabular}{|c|c|c|c|c|c|c|c|c|c|}
\hline & \multicolumn{3}{|c|}{ Nonthaburi } & \multicolumn{3}{|c|}{ Bangkok } & \multicolumn{3}{|c|}{ Pathum Thani } \\
\hline & $\begin{array}{l}\text { Low } \\
\text { income }\end{array}$ & $\begin{array}{l}\text { Middle } \\
\text { income }\end{array}$ & All & $\begin{array}{l}\text { Low } \\
\text { income }\end{array}$ & $\begin{array}{l}\text { Middle } \\
\text { Income }\end{array}$ & All & $\begin{array}{l}\text { Low } \\
\text { income }\end{array}$ & $\begin{array}{l}\text { Middle } \\
\text { income }\end{array}$ & All \\
\hline $\begin{array}{l}\text { \% of respondents who } \\
\text { owned the house they } \\
\text { were living in }\end{array}$ & 90.2 & 98.6 & 94.2 & 88.0 & 98.5 & 93.0 & 94.6 & 89.9 & 92.4 \\
\hline $\begin{array}{l}\text { Number of year lived } \\
\text { in this house }\end{array}$ & 25.3 & 15.0 & 20.5 & 30.2 & 7.3 & 19.2 & 22.0 & 7.2 & 15.2 \\
\hline
\end{tabular}


Table 1 continued

\begin{tabular}{|c|c|c|c|c|c|c|c|c|c|}
\hline & \multicolumn{3}{|c|}{ Nonthaburi } & \multicolumn{3}{|c|}{ Bangkok } & \multicolumn{3}{|c|}{ Pathum Thani } \\
\hline & $\begin{array}{l}\text { Low } \\
\text { income }\end{array}$ & $\begin{array}{l}\text { Middle } \\
\text { income }\end{array}$ & All & $\begin{array}{l}\text { Low } \\
\text { income }\end{array}$ & $\begin{array}{l}\text { Middle } \\
\text { Income }\end{array}$ & All & $\begin{array}{l}\text { Low } \\
\text { income }\end{array}$ & $\begin{array}{l}\text { Middle } \\
\text { income }\end{array}$ & All \\
\hline How old is the house & 58.0 & 30.2 & 44.9 & 40.7 & 7.8 & 25.0 & 27.0 & 22.6 & 25.0 \\
\hline $\begin{array}{l}\text { How many times has } \\
\text { house been flooded }\end{array}$ & 7 & 1 & 4 & 3 & 2 & 2.5 & 2 & 1 & 1.5 \\
\hline $\begin{array}{l}\text { House price before } \\
\text { flood (million Baht) }\end{array}$ & 0.368 & 3.48 & - & 0.316 & 4.67 & - & 0.295 & 1.5 & - \\
\hline \multicolumn{10}{|l|}{ Number of story } \\
\hline 1 & $\begin{array}{l}47 \\
(57.3)\end{array}$ & $\begin{array}{l}12 \\
(16.4)\end{array}$ & $\begin{array}{l}59 \\
(38.1)\end{array}$ & $\begin{array}{l}31 \\
(41.3)\end{array}$ & - & $\begin{array}{l}31 \\
(21.5)\end{array}$ & $\begin{array}{l}57 \\
(62.0)\end{array}$ & $\begin{array}{l}10 \\
(12.7)\end{array}$ & $\begin{array}{l}67 \\
(39.2)\end{array}$ \\
\hline 2 & $\begin{array}{l}35 \\
(42.7)\end{array}$ & $\begin{array}{l}60 \\
(82.2)\end{array}$ & $\begin{array}{l}95 \\
(61.3)\end{array}$ & $\begin{array}{l}44 \\
(58.7)\end{array}$ & $\begin{array}{l}69 \\
(100.0)\end{array}$ & $\begin{array}{l}113 \\
(78.5)\end{array}$ & $\begin{array}{l}35 \\
(38.0)\end{array}$ & $\begin{array}{l}67 \\
(84.8)\end{array}$ & $\begin{array}{l}102 \\
(59.6)\end{array}$ \\
\hline 3 & - & $\begin{array}{l}1 \\
(1.4)\end{array}$ & $\begin{array}{l}1 \\
(0.6)\end{array}$ & - & - & - & - & $\begin{array}{l}2 \\
(2.5) \\
\end{array}$ & $\begin{array}{l}2 \\
(1.2) \\
\end{array}$ \\
\hline Level of water $(\mathrm{cm})$ & \multicolumn{9}{|c|}{ Measured in centimeters from the ground } \\
\hline Road & 152.9 & 157.6 & 155.1 & 165.5 & 138.3 & 152.5 & 103.3 & 60 & 83.3 \\
\hline Soi (side road) & 155.2 & 156.1 & 155.7 & 167.4 & 147.5 & 157.8 & 145.5 & 144.2 & 144.9 \\
\hline Around of house & 186.2 & 127.3 & 158.4 & 178.8 & 124.4 & 152.7 & 132.6 & 112.7 & 123.4 \\
\hline Inside house & 124.3 & 93.3 & 109.7 & 157.6 & 62.2 & 111.9 & 106.1 & 90.5 & 98.9 \\
\hline Duration (days) & \multicolumn{9}{|c|}{ Number of days the water remained in the area } \\
\hline Road & 76.7 & 63.8 & 70.6 & 51.3 & 50.3 & 50.8 & 54.3 & 45.4 & 50.2 \\
\hline Soi (side road) & 78.2 & 63.9 & 71.4 & 52.4 & 52.8 & 52.5 & 65.5 & 60.6 & 63.3 \\
\hline Around of house & 83.8 & 60.2 & 72.6 & 55.4 & 49.4 & 52.5 & 67.4 & 55.8 & 62.0 \\
\hline Inside house & 76.5 & 57.2 & 67.4 & 53.6 & 42.3 & 48.2 & 63.5 & 52.6 & 58.4 \\
\hline
\end{tabular}

Note. Figures in ( ) are percentage of the total number of respondents in each group.

\section{Evacuation}

With the inside of the house being flooded, the majority of the households had to evacuate. Across all the three districts, there were higher percentages of middle income households that evacuated compared to the lower income. Even with difficult accessibility however, some members of the households refused to leave. In Nonthaburi, for example, $70 \%$ of the households evacuated. Among these, 55\% were cases where everyone left the house while for the remaining $45 \%$, some family members decided to stay behind. Evacuation details and associated expenses formed part of the calculation of household damages.

The period of evacuation was between 30 and nearly 50 days (see Table 2). Among those who evacuated, those who were income earners were asked about their temporary place of residence during the flooding period. Around $50 \%$ of respondents were living with relatives and friends whereas only $16 \%$ said they had to rent. The same pattern is true for middle-income respondents where around $76 \%$ said they were put up by friends and relatives. Around $18 \%$ said they had to rent apartments. Place of work (mainly government offices) also became temporary shelters. Only 3\% said they had to live in relief centres or temporary shelters by the roadside (see Figure 2). Among these temporary places, the only case where the respondents had to pay was if they had to rent rooms or apartments. Overall, this means that for over $70 \%$ of both respondent groups, there was no extra accommodation cost. This, in many respects, reflects the presence and benefits of social networks, which is still functioning even among urban dwellers. For those who had to pay, the low-income respondents paid on average 4,782 Baht for the whole period. The average accommodation cost for the middle-income respondents was 17,538 Baht. 
Table 2

Evacuation

\begin{tabular}{llllllllll}
\hline & \multicolumn{3}{c}{ Nonthaburi } & \multicolumn{3}{c}{ Bangkok } & \multicolumn{3}{c}{ Pathum Thani } \\
\cline { 2 - 9 } & $\begin{array}{l}\text { Low } \\
\text { income }\end{array}$ & $\begin{array}{l}\text { Middle } \\
\text { income }\end{array}$ & All & $\begin{array}{l}\text { Low } \\
\text { income }\end{array}$ & $\begin{array}{l}\text { Middle } \\
\text { income }\end{array}$ & All & $\begin{array}{l}\text { Low } \\
\text { income }\end{array}$ & $\begin{array}{l}\text { Middle } \\
\text { income }\end{array}$ & All \\
\hline Evacuated & 46 & 63 & 109 & 60 & 67 & 127 & 55 & 60 & 115 \\
Number of households with some & 58 & 12 & 70 & 26 & 7 & 33 & 52 & 36 & 88 \\
members of the family evacuating & $(70.7)$ & $(16.4)$ & $(45.2)$ & $(34.7)$ & $(10.1)$ & $(22.9)$ & $(56.5)$ & $(45.6)$ & $(51.5)$ \\
Number of households where the & 24 & 61 & 85 & 49 & 62 & 111 & 40 & 43 & 83 \\
entire household evacuated & $(29.3)$ & $(83.6)$ & $(54.8)$ & $(65.3)$ & $(89.9)$ & $(77.1)$ & $(43.5)$ & $(54.4)$ & $(48.5)$ \\
Number of days evacuated & 29 & 49 & 39 & 38 & 45 & 42 & 35 & 36 & 36 \\
Alternative accommodation & 5,017 & 20,799 & 16,740 & 4,193 & 17,156 & 12,835 & 5,341 & 8,275 & 6,576 \\
expenses (THB) & {$[4,406]$} & {$[14,054]$} & {$[14,099]$} & {$[4,053]$} & {$[16,341]$} & {$[14,809]$} & {$[5,133]$} & {$[9,312]$} & {$[7,112]$} \\
\hline
\end{tabular}

Notes. Figures in ( ) are percentage of the total number of respondents in each group; Figures in [ ] are standard deviations.
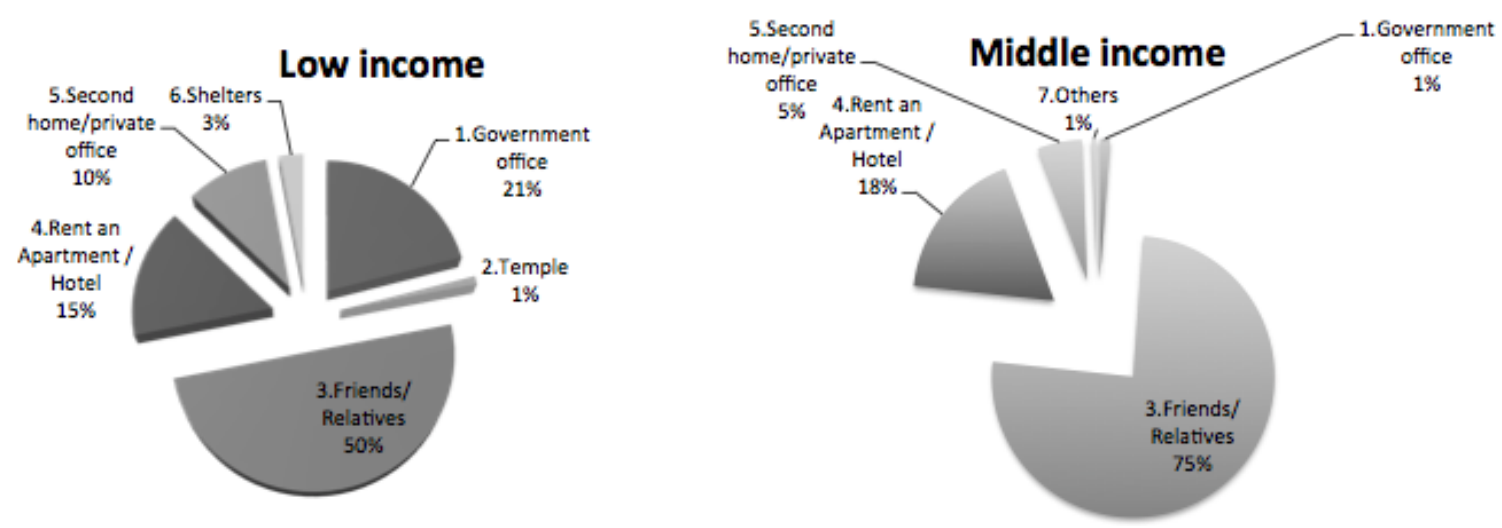

Figure 2. Temporary places of residence during evacuation.

\section{Household 2011 Flood Damages}

Table 3

Total Damages Compared to House Prices and Annual Income

\begin{tabular}{lccc}
\hline & Damage (Baht/hh) & Damage as \% of house price & Damage as \% of estimated household income \\
\hline Nonthaburi & & & \\
Low income & 70,782 & 19.2 & 31.5 \\
Middle income & 308,764 & 8.9 & 46.8 \\
Bangkok & & & \\
Low income & 81,234 & 25.7 & 24.8 \\
Middle income & 337,767 & 7.2 & 25.6 \\
Pathum Thani & & & \\
Low income & 77,767 & 26.4 & 26.7 \\
Middle income & 144,606 & 9.6 & 13.7 \\
\hline
\end{tabular}

Mean value of damages ranged from 70,782 Baht/household in Nonthaburi, to 77,767 Baht/household, and 81,234 Baht/household in Bangkok. The mean value of damages between low and middle income was as expected statistically significant different in all three provinces. Among the middle-income households, there were no significant differences of the total damages between Nonthaburi and Bangkok. However, the damages in both these provinces were significantly higher than Pathum Thani. Relative to house prices, the total damages for the low income communities are equivalent to around $25 \%$ of self-reported house prices. For 
middle-income households, the total damages for all three districts were under $10 \%$. Compared to estimated annual household income, the total damages were quite substantial ranging from the lowest of around 13\% to the highest ratio in both low and middle income communities in Nonthaburi of $31.5 \%$ and $46.8 \%$ respectively (see Table 3).

\section{Compensation}

The costs of the households in the flooded areas were partially offset by the compensation they received. In principle, all of the households in flooded areas were entitled to receive compensation from the central government. So long as the area is officially declared as flooded, households will automatically receive 5,000 Baht delivered by the local governments. Households were also entitled to receive additional compensation up to 30,000 Baht but this was subject to provision of photographs of the damages and providing a list of damaged property and estimated price. Some households also received compensation from their employers. By 2012 during round 2 surveys, all households have received the compensation from all available sources. In this paper, compensation from all sources was aggregated and used this to compare with the total value of the damages as well as the value of coverage households would have received if mechanisms such as flood insurance were available back in $2011 .^{5}$

Although compensation was subject to the households providing evidences, there was a maximum value of compensation that can be approved. As such, there was not much variation in the compensation received, which ranged from around 20,000 Baht/household to 25,000 Baht. For the low-income group, the compensation received compared to the damage values ranged from $26 \%$ to $30 \%$. Among the middle income however, there was a wider gap between the Nonthaburi and Bangkok respondents and Pathum Thani on the value of compensation received compared to the damage values received varying due to the difference in the monetary value of damages. Overall, with the value of compensation being low compared to the damages incurred, net losses for the low income were around 57,000 Baht/households. Net losses for the middle income averaged at 240,000 Baht/household. Again, the net losses for middle-income households in both Nonthaburi and Bangkok were significantly higher than Pathum Thani (see Table 4).

Table 4

Compensation Compared to Damages

\begin{tabular}{|c|c|c|c|c|}
\hline & Damage (Baht/hh) & Total Compensation (Baht/hh) & Loss (Baht/hh) & Compensation/ Damage (\%) \\
\hline \multicolumn{5}{|l|}{ Nonthaburi } \\
\hline Low income & 79,782 & 24,465 & 55,317 & 30.7 \\
\hline Middle income & 308,764 & 25,588 & 283,176 & 8.3 \\
\hline \multicolumn{5}{|l|}{ Bangkok } \\
\hline Low income & 81,234 & 21,786 & 59,448 & 26.8 \\
\hline Middle income & 337,767 & 20,202 & 317,565 & 6.0 \\
\hline \multicolumn{5}{|l|}{ Pathum Thani } \\
\hline Low income & 77,767 & 20,402 & 57,365 & 26.2 \\
\hline Middle income & 144,606 & 24,430 & 120,176 & 16.9 \\
\hline
\end{tabular}

\section{Factors Affecting Extent of Damages}

\footnotetext{
${ }^{5}$ As of March 2012, Bangkok Metropolitan Administration reported that 1,089,242 households in Bangkok have applied for the initial 5,000 Baht. In Don Muang, one of our study site and a district in Bangkok, altogether 64,735 have applied for compensation. The reported number of households affected by the flood in Pathum Thani and Nonthaburi was 354,707 households and 368,300 households.
} 
On factors that influenced amount of flooding damages by households, regression analysis results have shown that the wealthier the households (as indicated by having higher household income and house prices), the higher the total damages. The number of stories was significant for all the models except Pathum Thani. As expected, the coefficient sign is negative indicating that two story houses incurred less damages than one story houses. The level of the water in the ground floor was a significant determinant of the damages in the Pathum Thani Model with positive coefficient sign conforming to a priori expectation that the greater the depth, the higher the damage will be(Table 5).

Table 5

Factors that Determine the Extent of the Total Damages

\begin{tabular}{lllll}
\hline & Nonthaburi & Bangkok & Pathum Thani & Pooled \\
\hline & & & & \\
(Constant) & $47,395.532$ & $47,868.331$ & $16,078.483$ & $44,694.308$ \\
est_hh_inc & $1.223^{* * *}$ & 0.144 & $1.452^{* * * *}$ & $0.471^{* * *}$ \\
house price before flood & $0.047^{* * *}$ & 0.06 & $0.035^{* * *}$ & $0.053^{* * *}$ \\
number of stories & $-58,188.927^{*}$ & $-37,663.368^{* * *}$ & $-17,169.614$ & $-30,897.095^{*}$ \\
level of water in the ground floor & 234.735 & 272.002 & 227.374 & $251.103^{*}$ \\
$r$ square & 0.49 & 0.31 & 0.378 & 0.38 \\
\hline $\begin{array}{l}\text { Notes. } \\
\text { confidence. }\end{array}$ & & &
\end{tabular}

\section{Demand for Flood Insurance}

At the time of Round 1 survey, only 17 respondents from the 469 households had flood insurance before the 2011 flood incidence. By the time Round 2 survey was conducted, the number of those with flood insurance had increased by 18 to 35 respondents. This is a significant increase from the pre-flooding data but is still considered low, given the massive impact of the 2011 flooding. Among the middle-income households between $8 \%-16 \%$ it had bought flood insurance (see Table 6). All of these respondents were from middle-income households and two story houses with average price of 3,000,000 Baht. Based on information on the premium and coverage, none of the flood insurance bought after the 2011 flood, was the one provided through the National Catastrophe Insurance Fund (NCIF). Moreover, whether or not these respondents were motivated to have flood insurance because the experience from the 2011 flood cannot be confirmed. This is because most of these were insurances not specifically related to floods but joint coverage for fire and flood. The providers were mainly commercial banks. The difference between the pre and post 2011 flood was that after 2011 flood, all applicants for loans from commercial banks for house purchase were required to purchase a package of fire and flood insurance.

Table 6

Awareness About the Flood Insurance Under the National Catastrophe Insurance Fund

\begin{tabular}{|c|c|c|c|c|c|c|}
\hline & \multicolumn{2}{|c|}{ Nonthaburi } & \multicolumn{2}{|c|}{ Bangkok } & \multicolumn{2}{|c|}{ Pathum Thani } \\
\hline & Low income & $\begin{array}{l}\text { Middle } \\
\text { income }\end{array}$ & Low income & $\begin{array}{l}\text { Middle } \\
\text { income }\end{array}$ & Low income & $\begin{array}{l}\text { Middle } \\
\text { income }\end{array}$ \\
\hline $\begin{array}{l}\text { \% who knew about NCIF flood insurance } \\
\text { programme }\end{array}$ & $\begin{array}{l}25 \\
(30.5)\end{array}$ & $\begin{array}{l}57 \\
(78.1)\end{array}$ & $\begin{array}{l}26 \\
(34.7)\end{array}$ & $\begin{array}{l}47 \\
(69.1)\end{array}$ & $\begin{array}{l}25 \\
(27.2)\end{array}$ & $\begin{array}{l}59 \\
(74.7)\end{array}$ \\
\hline $\begin{array}{l}\text { \% with flood insurance after the } 2011 \\
\text { flooding event }\end{array}$ & 0 & $\begin{array}{l}8 \\
(11.0)\end{array}$ & 0 & $\begin{array}{l}16 \\
(23.5)\end{array}$ & $\begin{array}{l}1 \\
(1.1)\end{array}$ & $\begin{array}{l}10 \\
(12.7)\end{array}$ \\
\hline
\end{tabular}

Note. Figures in ( ) parenthesis are percentages of the number of respondents in that group. 
To explore demand for flood insurance, the respondents were asked if they will be interested in purchasing flood insurance, by giving them the features of the NCIF flood insurance program.

For this part of the survey, the enumerators were asked to "read" information script translated in Thai language below. Care was taken to ensure that interviewers do not offer any additional information that would influence decision-making in either direction. ${ }^{6}$ Card 1 and 2 provide basic information about flood insurance. Card 3 is a chart explaining how flood insurance works. Card 4 provides information about insurance premium. Card 5 describes the basic conditions that will determine the amount of compensation that will be received.

\section{CARD 1:}

- One way of reducing the risk from floods is to purchase flood insurance;

- When you purchase car insurance, you agree to pay a premium according to the contract. If an accident happens, the insurance company will cover your loss. How much they pay will depend on the type of car insurance you buy, i.e., Class 1, 2, or 3;

- But if there is no accident, the insurance companies will not pay anything.

CARD 2:

- The principle of flood insurance is the same. You pay a premium to the insurance company;

- If there is a flood and your house and properties are damaged, the insurance will pay you money to cover your losses. How much is paid depends on the type of insurance you purchased and the extent of your losses;

- But if there is no flood, the insurance companies will not pay anything.

The enumerators then provide some information about the NCIF as follows:

CARD 3:

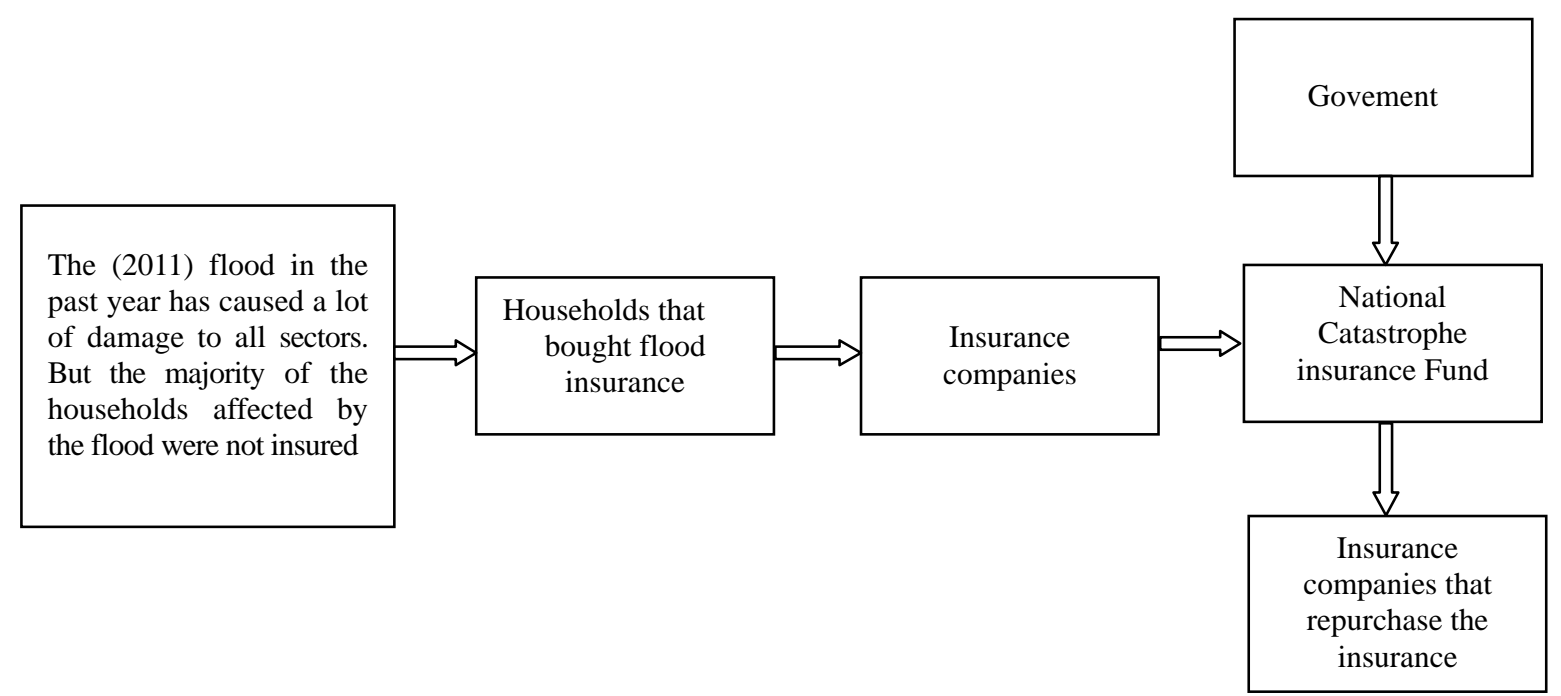

CARD 4:

Households will pay $0.5 \%$ of the maximum coverage and payment conditions will be as follows:

- If water reaches the floor inside of your house, pay $30 \%$ or 30,000 Baht;

- If the depth of the water inside your house is $50 \mathrm{~cm}$, pay $50 \%$ or 50,000 Baht;

- If the depth of the water inside your house is $75 \mathrm{~cm}$, pay $75 \%$ or 75,000 Baht;

\footnotetext{
6 The information provided, presented in five Cards, has been discussed in Focus Groups with local low and middle income communities in flooded areas adjacent to the study areas in Nonthaburi.
} 
- If the depth of the water inside your house reaches $100 \mathrm{~cm}$, pay $100 \%$ or 100,000 Baht;

- If water does not get inside your house, the insurance company will not pay anything. CARD 5:

- The sum of payment will depend on the assessment of the damages by the insurance;

- Companies;

- If your house is located in areas designated as floodways, you will not be eligible to buy flood insurance under the NCIF since you will receive compensation from the government;

- Households can purchase flood insurance that provides a higher coverage than the maximum 100,000 Baht but the premium will be higher as well and would depend on the policy of the insurance companies as well as the flood risk of the location;

- Not only homeowners, but also tenants are also eligible to purchase flood insurance.

After providing this brief information, the respondents are asked whether they would be willing to buy the flood insurance if they had to pay a premium of 500 Baht/year. Responses in Table 7 indicate that the percentages of the middle-income respondents who said they were willing to purchase flood insurance ranged from the lowest at $\mathbf{2 4 . 7 \%}$ in Nonthaburi to around $41 \%$ for Bangkok and Pathum Thani. Within the provinces, the percentage of middle-income households willing to buy flood insurance was all higher than lower income respondents. Since, households had the option to pay higher annual premiums, which would entitle them to higher coverage, a follow-up question was posed whether they would also be interested. Responses also suggest that once respondents have decided to buy the flood insurance, the majority are also willing to pay a premium higher than 500 Baht per year for a coverage that is higher than 100,000 Baht.

Table 7

Percentage of Respondents Willing to Buy Flood Insurance

\begin{tabular}{|c|c|c|c|c|c|c|}
\hline & \multicolumn{2}{|c|}{ Nonthaburi } & \multicolumn{2}{|c|}{ Bangkok } & \multicolumn{2}{|c|}{ Pathum Thani } \\
\hline & Low income & Middle income & Low income & Middle income & Low income & Middle income \\
\hline Buy insurance & $\begin{array}{l}15 \\
(18.3)\end{array}$ & $\begin{array}{l}18 \\
(24.7)\end{array}$ & $\begin{array}{l}19 \\
(25.3)\end{array}$ & $\begin{array}{l}30 \\
(41.1)\end{array}$ & $\begin{array}{l}21 \\
(22.8)\end{array}$ & $\begin{array}{l}33 \\
(41.8)\end{array}$ \\
\hline $\begin{array}{l}\% \text { who will buy } \\
\text { to pay a higher } \\
\text { premium }\end{array}$ & 66.7 & 66.7 & 66.7 & 89.5 & 66.7 & 71.4 \\
\hline \multicolumn{7}{|c|}{ Reasons for not buying flood insurance } \\
\hline & $\begin{array}{l}\text { There is very } \\
\text { little chance of } \\
\text { flood } \\
\text { reoccurring } \\
(36.4 \%)\end{array}$ & $\begin{array}{l}\text { It is most likely to } \\
\text { be a waste of } \\
\text { money } \\
(25.9 \%)\end{array}$ & $\begin{array}{l}\text { There is very } \\
\text { little chance of } \\
\text { flood reoccurring } \\
(28.8 \%) \\
\text { Need more }\end{array}$ & $\begin{array}{l}\text { There is very } \\
\text { little chance of } \\
\text { flood reoccurring } \\
-21.6\end{array}$ & $\begin{array}{l}\text { There is very little } \\
\text { chance of flood } \\
\text { reoccurring } \\
(43.7 \%)\end{array}$ & $\begin{array}{l}\text { There is very } \\
\text { little chance of } \\
\text { flood } \\
\text { reoccurring } \\
(73.9 \%)\end{array}$ \\
\hline Second & $\begin{array}{l}\text { It is most likely } \\
\text { to be a waste of } \\
\text { money }\end{array}$ & $\begin{array}{l}\text { There is very little } \\
\text { chance of flood } \\
\text { reoccurring }\end{array}$ & $\begin{array}{l}\text { information about } \\
\text { flood risk in the } \\
\text { neighbourhood } \\
\text { area }\end{array}$ & $\begin{array}{l}\text { It is most likely } \\
\text { to be a waste of } \\
\text { money }\end{array}$ & $\begin{array}{l}\text { It is most likely to } \\
\text { be a waste of } \\
\text { money }\end{array}$ & $\begin{array}{l}\text { It is most likely } \\
\text { to be a waste of } \\
\text { money }\end{array}$ \\
\hline & $(16.7 \%)$ & $(24.1 \%)$ & $(16.1 \%)$ & $(21.6 \%)$ & $(12.7 \%)$ & $(10.9 \%)$ \\
\hline Third & $\begin{array}{l}\text { The premium is } \\
\text { high when } \\
\text { considering the } \\
\text { low probability } \\
\text { of flood } \\
\text { reoccurring } \\
(12.1 \%)\end{array}$ & $\begin{array}{l}\text { Need more } \\
\text { information about } \\
\text { flood risk in the } \\
\text { neighbourhood } \\
\text { area } \\
(11.1 \%)\end{array}$ & $\begin{array}{l}\text { It is most likely to } \\
\text { be a waste of } \\
\text { money }\end{array}$ & $\begin{array}{l}\text { Need more } \\
\text { information } \\
\text { about flood risk } \\
\text { in the } \\
\text { neighborhoods } \\
\text { area } \\
(16.2 \%)\end{array}$ & $\begin{array}{l}\text { The premium is } \\
\text { high when } \\
\text { considering the } \\
\text { low probability of } \\
\text { flood reoccurring } \\
(12.7 \%)\end{array}$ & $\begin{array}{l}\text { Not owner of } \\
\text { the house }\end{array}$ \\
\hline
\end{tabular}


As for the reasons why around 70\% people did not want to buy flood insurance, the most common was the perception that there is a small chance that flood like 2011 reoccurs and that paying at most 500 Baht/year was going to be a waste of money. Many also cited the need for more information as a reason. Though the majority of respondents across neighbourhoods are not willing to buy the flood insurance, when asked their general opinion about the conditions for claims under the flood insurance contract, over $70 \%$ agree with the conditions for payment-for those who do not, it is mainly because payments do not take into account loss of income during the flood, the extent of the damage and observing that insurance companies often underestimate the extent of the damages, the need for clear criteria for payment.

Results from the logit regression to explore which factors influenced desire to buy insurance in Table 8 show that for the provincial models and the pooled model. What is consistent across models is that risk perception did not influence decision-making. Surprisingly, factors that indicated how normal daily life was disrupted such as depth and duration of the water inside their houses also had limited influence.

There is no consistent pattern across the different categories of respondents. Houseprice was significant variable in the Nonthaburi. The coefficient sign, as expected, was positive indicating that the higher the house prices, the higher the probability that respondents would decide to buy flood insurance will be.

The only model where the variable knew insurance (whether or not respondents had information about the NCIF flood insurance program prior to the survey was significant determinant factor with positive coefficient signs) was the Bangkok Model. Age was significant factor in three models (Nonthaburi Model, Pathum Thani, and the Pooled Model). In these models, the age coefficient sign is negative indicating the greater likelihood of respondents who were younger to purchase the flood insurance under the NCIF programme.

Table 8

Determinants of Willingness to Buy Flood Insurance: Pooled Model

\begin{tabular}{|c|c|c|c|c|}
\hline & Nonthaburi & Bangkok & Pathum Thani & Pooled \\
\hline know_insurance & -0.112 & $0.855^{* *}$ & -0.142 & 0.284 \\
\hline homeowner & 0.731 & 0.166 & -0.054 & -0.006 \\
\hline houseprice & $0.000^{*}$ & 0.000 & 0.000 & 0.000 \\
\hline storys & 0.469 & -0.131 & -0.331 & -0.101 \\
\hline age & $-0.039^{* *}$ & -0.004 & $-0.047^{* *}$ & $-0.026^{* * *}$ \\
\hline edu & -0.041 & 0.000 & 0.021 & -0.013 \\
\hline total damages & 0.000 & 0.000 & 0.000 & 0.000 \\
\hline height4 & -0.002 & -0.004 & 0.007 & 0.000 \\
\hline duration4 & 0.001 & 0.005 & -0.015 & -0.002 \\
\hline riskperception & -0.308 & 0.436 & -0.134 & 0.144 \\
\hline income_dummy & 1.185 & -0.409 & 0.663 & 0.843 \\
\hline b_bangkok & & & & $0.738^{* *}$ \\
\hline d_pathum & & & & $0.353^{* *}$ \\
\hline Constant & 0.287 & -1.042 & 0.965 & -0.228 \\
\hline -2 Log likelihood & 140.796 & 156.74 & 167.443 & 481.874 \\
\hline
\end{tabular}

Notes. $^{* * *}$ significant at 99\% level of confidence; ${ }^{* *}$ significant at 95\% level of confidence; and ${ }^{*}$ significant at $90 \%$ level of confidence.

Contrary to expectation, the total damages incurred were not a factor that influenced decision making in any of the models. What is also notable is that whether or not this policy of providing floods insurance under 
the NCIF exists, does not affect people welfare either positively or negatively, as none of constant variable in the models was significant. The results of the logit regression are also consistent with the pattern of response why people did not want to buy the flood insurance. Although just over half of the respondents thought that the chances of a flood as severe as 2011 were over $70 \%$, the variable risk perception was not a significant factor. The two provincial dummy variables were significant suggesting that there were higher probabilities that respondents in Bangkok and Pathum Thani will buy flood insurance than respondents in Nonthaburi.

With compensation being at most $30 \%$ of the value of the damages and with a negligible percentage of the respondents having flood insurance, the percentage of respondents who think they want to buy flood insurance was lower than expected. This is because damages incurred by households have been quite substantial, particularly compared in terms of percentage of income. On top of that, there has been disruption of normal daily life for extended periods. Over half of the respondents also thought that the chances of a flood as severe as 2011 is $70 \%$ or higher. In Table 9, given the flood depth of the neighbourhoods covered by the survey, in principle, households would have received a substantial proportion of the losses. Given the flood depth of over 100 centimeters, all low-income respondents would be entitled to the maximum insurance coverage of 100,000 Baht, which is a sum that also exceeds the total damage costs. For middle income households, the insurance coverage would be lower because house prices is higher and assessment is based on the flood depth inside the house and as discussed earlier, flood depth of lower income houses in all three districts are significantly higher than in middle income neighbourhoods. Based on the information, it would seem that the decision to buy flood insurance is not determined by a clear cut influence of any single factor, such as the damages incurred from the 2011 flood, the perception of risks from future floods, the value of property, the affordability to invest in preventive measures or even the vulnerability of the neighbourhood compared to other adjacent areas. Instead, these factors combined could be reasons why on the whole, households made decisions not to buy flood insurance.

Table 9

Compensation and Insurance Coverage and Total Damages

\begin{tabular}{|c|c|c|c|c|c|c|}
\hline & \multicolumn{2}{|c|}{ Nonthaburi } & \multicolumn{2}{|c|}{ Bangkok } & \multicolumn{2}{|c|}{ Pathum Thani } \\
\hline & Low income & Middle income & Low income & Middle income & Low income & Middle income \\
\hline Total damages & 70,782 & 308,764 & 81,234 & 337,767 & 77,966 & 144,606 \\
\hline Value of compensation received & 24,465 & 25,588 & 21,786 & 20,202 & 20,402 & 24,430 \\
\hline $\begin{array}{l}\text { Compensation as percentage of } \\
\text { damages }\end{array}$ & $33 \%$ & $8 \%$ & $27 \%$ & $6 \%$ & $26 \%$ & $17 \%$ \\
\hline $\begin{array}{l}\text { Flood depth inside the house } \\
(\mathrm{cm})\end{array}$ & 124.3 & 93.3 & 157.6 & 62.2 & 106.1 & 90.5 \\
\hline $\begin{array}{l}\text { maximum coverage with flood } \\
\text { insurance }\end{array}$ & 100,000 & 75,000 & 100,000 & 50,000 & 100,000 & 75,000 \\
\hline $\begin{array}{l}\text { insurance coverage as } \\
\text { percentage of total damages }\end{array}$ & $141.28 \%$ & $24.29 \%$ & $123.10 \%$ & $14.80 \%$ & $128.26 \%$ & $51.87 \%$ \\
\hline
\end{tabular}

\section{Conclusions}

The main findings of this study have been that the lower income neighbourhood in all the three districts was harder hit by the 2011 flood in terms of both flood depth and duration. Based on aggregation of both direct and indirect costs, the monetary value of the total economic damages both in the period before and during the flood of the middle income households was significantly higher than the lower income respondents. This is also 
the case for both the periods before and during the flood. Relative to house prices, the total damages to self-reported house prices for low income and middle-income communities were respectively $25 \%$ and $10 \%$. The damages compared to estimated annual household income was the highest in Nonthaburi where speed of the rise in flood depth was the fastest among the three study areas and was equivalent to $35 \%$ of annual income of the lower income respondents in this province and as high as $46.8 \%$ of the annual revenue of the middle income households.

The percentages of households willing to purchase flood insurance were lower than expected particularly when considering that flood insurance coverage would have been higher than compensation received. Based on information about insurance premiums and coverage provided as part of the survey design, there was a higher percentage of middle-income households who stated that they were willing to purchase flood insurance. This was surprising when considering that (1) the affordability issue can more or less be ruled out with the low premium of 500 Baht and (2) the mean flood depth inside the house in the low-income neighbourhood that exceeded $100 \mathrm{~cm}$ would have entitled those with flood insurance to full coverage if another flood as severe as 2011 was to hit the area. While house prices, age, and knowledge about flood insurance were variables that significantly influence household's decision to purchase flood insurance, there was no consistent across the models. Decisions depend on a combination of factors and are not clearly determined by any single factor. There may be some insights from some of the reasons people gave for deciding not to buy flood insurance, which is about the probability of a severe flood reoccurring and about needing more neighbourhood specific information about risks. Although it is not the objective of this study to advocate households buying flood insurance, findings from this study, particularly comparisons made in terms of damages and insurance coverage, may provide a more solid base on which households can make decisions whether or not to insure their houses against future floods.

\section{References}

Dutta, D., Herath, S., \& Musiake, K. (2003). A mathematical model for flood loss estimation. J. Hydrol., 277, $24-49$.

GISTDA. (2011). Radar satellite images and flood maps of the 2011 flood. Retrieved May-December 2011 from http://www.gistda.or.th

Merz, B., \& Thieken, A. H. (2004). Flood risk analysis: Concepts and challenges. Oesterr. Wasser Abfallwirtschaft, 56(3-4), 27-34.

Nabangchang, O., Allaire, M., Leangcharoen, P., Jarungrattanapong, R., \& Whittington D. (2014). Economic costs incurred by households in the 2011 Bangkok flood. EEPSEA Research Report.

Poapongsakorn, N., \& Meethom, P. (2012). Impact of the 2011 floods, and flood management in Thailand. In Y. Sawada, \& S. Oum (Eds.), Economic and welfare impacts of disasters in East Asia and policy responses (pp. 243-306). ERIA Research Project Report 2011-8, Jakarta: ERIA.

Smith, K., \& Ward, R. (1998). Floods: Physical processes and human impact. Hoboken, N.J.: John Wiley.

Suppaisarn, C. (2011). Medium and heavy flood management in Chao Phraya River Basin following the royal initiative. Bangkok: Thailand Research Fund Seminar.

Thieken, A. H., Muller, M., Kreibich, H., \& Merz, B. (2005). Flood damage and influencing factors: New insights from the August 2002 flood in Germany. Water Resources Research No. 41.

White, G. F., Kates, R. W., \& Burton, I. (2001). Knowing better and losing even more: The use of knowledge in hazards management. Environmental Hazards: Human and Policy Dimensions, 3(3-4), 81-92.

World Bank. (2012). Thai flood 2011: Rapid assessment for resilient recovery and reconstruction planning. Washington, DC: World Bank. 